\title{
National Indicators for Quality of Drug Therapy in Older Persons: the Swedish Experience from the First 10 Years
}

\author{
Johan Fastbom • Kristina Johnell
}

Published online: 12 February 2015

(C) The Author(s) 2015. This article is published with open access at Springerlink.com

\begin{abstract}
Inappropriate drug use is an important health problem in elderly persons. Beginning with the Beers' criteria in the early 1990s, explicit criteria have been extensively used to measure and improve quality of drug use in older people. This article describes the Swedish indicators for quality of drug therapy in the elderly, introduced in 2004 and updated in 2010. These indicators were designed to be applied to people aged 75 years and over, regardless of residence and other characteristics. The indicators are divided into drug specific, covering choice, indication and dosage of drugs, polypharmacy, drug-drug interactions (DDIs), drug use in decreased renal function and in some symptoms; and diagnosis specific, covering the rational, irrational and hazardous drug use in common disorders in elderly people. During the 10 years since introduction, the Swedish indicators have several applications. They form the basis for recommendations for drug therapy in older people, are implemented in prescribing supports and drug utilisation reviews, are used in national benchmarking of the quality of Swedish healthcare and have contributed to initiatives from pensioner organisations. The indicators have also been used in several pharmacoepidemiological studies. Since 2005, there have been signs of improvement of the quality of drug prescribing to elderly persons in Sweden. For example, the prescribing of drugs that should be avoided in older persons decreased by $36 \%$ between 2006 and 2012 in persons aged 80 years and older. Similarly, drug combinations that may cause DDIs decreased by $26 \%$ and antipsychotics by $41 \%$. The indicators have likely contributed to this.
\end{abstract}

J. Fastbom $(\bowtie) \cdot$ K. Johnell

Aging Research Center, Karolinska Institutet and Stockholm

University, Gävlegatan 16, 11330 Stockholm, Sweden

e-mail: johan.fastbom@ki.se

\section{Key Points}

The Swedish indicators cover both drug- and diagnosis-specific aspects of quality of drug therapy in elderly persons.

Since introduction in 2004, the Swedish indicators are widely implemented and have several applications in healthcare and research.

Since 2005, there have been several signs of improvement of the quality of drug prescribing to the elderly population in Sweden.

\section{Introduction}

Drug use is extensive in elderly persons [1-4]. Drug therapy in older people is also complicated by age-related pharmacokinetic and pharmacodynamic changes, which increase the sensitivity to many drugs. This, together with the extensive use of drugs and high prevalence of comorbidities, substantially increase the risk of untoward effects of drugs in old age $[5,6]$.

Inappropriate drug use (IDU) is an important health problem in elderly persons and is associated with adverse drug reactions, hospitalization, and mortality [7-11]. Previous studies have reported prevalences of IDU of $12-62 \%$ in older people [12-16], varying greatly with regard to participants, setting and means of measuring IDU.

In Sweden, drug prescriptions to older people grew significantly from the late 1980s and onwards, particularly 
over the following decade when the mean number of drugs per person aged 80 years and older increased by over onethird [17]. Furthermore, a study of a Swedish nationally representative survey reported a threefold increase in the prevalence of polypharmacy - as defined by the use of five or more drugs-from $18 \%$ in 1992 to $42 \%$ in 2002 [18]. In two particularly vulnerable groups, nursing-home residents and elderly with multimorbidity, medication use was reported to amount to approximately ten drugs per person at the beginning of the 21st century [19-22].

Potentially, IDU was also abundant in Sweden at that time. In a study on drug use in nursing homes in 2002, the use of long-acting benzodiazepines and anticholinergic drugs - both with a high risk of side effects in older persons-was reported to be 15 and $20 \%$, respectively, and more than one in four residents were treated with three or more psychotropic drugs [21]. Similar results were obtained from another study of 21 nursing homes in southern Sweden the same year [20].

In the year 2000, the Swedish government commissioned the Swedish National Board of Health and Welfare to develop indicators for quality of drug therapy in the elderly. The first version of the indicators was released in 2004 [23] and a revised version was issued in 2010 [24]. In this review, we describe the Swedish indicators and compare them with other criteria/indicators for quality of medication treatment in elderly persons. We also describe how they have been employed over the years in healthcare and research, by authorities and by the elderly community in Sweden, and how the quality of drug use has changed over time.

\section{Criteria for Quality of Drug Prescribing in Elderly Persons}

Inappropriate drug prescribing/use may be defined as the prescribing/use of drugs where the risk outweighs the benefit. Principally, this comprises the choice of drug, the dosage and length of therapy, the combination of drugs (drug duplication and drug-drug interactions [DDIs]), drug-disease interactions [25] and, finally, underprescribing/use. The latter is also sometimes called therapy omission, i.e. the omission of drug treatment that is clinically indicated and likely to be beneficial for the patient.

Since the beginning of the 1990s, several sets of criteria have been developed to measure quality of drug use in older people and to guide healthcare professionals in ensuring the high quality and safety of drug therapy in this vulnerable patient group. The criteria can be divided into implicit and explicit [26, 27]. The implicit criteria are based on the clinical judgement of the drug therapy based on information about and from an individual patient. They rely largely on the expertise of the examiner and are generally time-consuming. In contrast, the explicit criteria consist of lists of criteria, mainly based on inappropriate drugs and drug treatment in certain medical conditions, that are to be generally applicable to patients in a target population, for example persons aged 65 years and older. They are intended to be easy to use and to enable a structured way of measuring/ evaluating quality of drug use. The following sections briefly describe some of the most important explicit criteria. Their main features are also listed in Table 1. All of the criteria listed below, other than the Australian Prescribing Indicators Tool (see Sect. 2.4), were derived from a consensus panel using a Delphi technique.

\subsection{Beers' Criteria}

Beers' criteria were the first explicit criteria for medication use in the elderly, first published in 1991, and have since then become the most cited and employed criteria in pharmacoepidemiological studies. While the first version [28] only comprised drugs to be avoided and doses, frequencies or durations not to be exceeded, and was restricted to nursing-home residents, later updates [29-31] have included diagnosis/syndrome-specific criteria and target the elderly in general. Beers' criteria have been criticised [26] mainly for being incomplete and poorly applicable outside the US. In fact, a large proportion of the included drugs have been reported not to be listed in European drug formularies [32]. The most recent update [31] shows improvements, but still lacks some aspects of quality of drug use, such as DDIs, drug duplications and underprescribing (therapy omissions).

\subsection{McLeod's Criteria}

In parallel with the second update of the Beers' criteria, McLeod and coworkers in Canada developed a list of 'inappropriate practices', with the aim of overcoming some of the limitations of the Beers' criteria. The practices were divided into three categories: drugs generally contraindicated for elderly people, drug-disease interactions and DDIs. For each practice, alternative therapies were recommended [33].

\subsection{French Consensus Panel List}

The French consensus panel list was the first European criteria to be acknowledged internationally [34]. They were partly based on previous criteria, such as the Beers' and McLeod's criteria, but were much adapted to French drug formulary and guidelines. Apart from drugs to be avoided, they include aspects of drug duplications and drug-disease interactions. The list also suggests alternative drugs. 
Table 1 Summary and comparison of the most common explicit criteria/indicators for quality of drug therapy in elderly people

\begin{tabular}{|c|c|c|c|c|c|c|}
\hline References & $\begin{array}{l}\text { Criteria/ } \\
\text { indicators }\end{array}$ & Country & $\begin{array}{l}\text { Target } \\
\text { population }\end{array}$ & Structure & $\begin{array}{l}\text { Addressing } \\
\text { prescribing } \\
\text { omissions }\end{array}$ & Other features \\
\hline Beers et al. [28] & $\begin{array}{l}\text { Beers' } \\
\text { criteria, } \\
1991\end{array}$ & US & $\begin{array}{l}\text { Nursing } \\
\text { home } \\
\text { residents } \\
\geq 65 \text { years }\end{array}$ & $\begin{array}{l}19 \text { Criteria on drugs that should be } \\
\text { avoided and } 11 \text { on doses, } \\
\text { frequencies or durations not to be } \\
\text { exceeded }\end{array}$ & No & \\
\hline Beers [29] & $\begin{array}{l}\text { Beers' } \\
\text { criteria, } \\
1997\end{array}$ & US & $\begin{array}{l}\text { All elderly } \\
\geq 65 \text { years }\end{array}$ & $\begin{array}{l}28 \text { Criteria on PIM use and } 35 \\
\text { criteria on PIM in } 15 \text { diagnoses }\end{array}$ & No & \\
\hline Fick et al. [30] & $\begin{array}{l}\text { Beers' } \\
\text { criteria, } \\
2003\end{array}$ & US & $\begin{array}{l}\text { All elderly } \\
\geq 65 \text { years }\end{array}$ & $\begin{array}{l}48 \text { Drugs to be avoided. Drugs to be } \\
\text { avoided in } 20 \text { diseases/conditions }\end{array}$ & No & \\
\hline $\begin{array}{l}\text { American Geriatrics } \\
\text { Society [31] }\end{array}$ & $\begin{array}{l}\text { Beers' } \\
\text { criteria, } \\
2012\end{array}$ & US & $\begin{array}{l}\text { All elderly } \\
\geq 65 \text { years }\end{array}$ & $\begin{array}{l}34 \text { PIMs to avoid, PIMs to avoid in } \\
14 \text { diseases/syndromes, } 13 \text { drugs } \\
\text { to be used with caution }\end{array}$ & No & \\
\hline McLeod et al. [33] & $\begin{array}{l}\text { McLeod's/ } \\
\text { Canadian } \\
\text { criteria }\end{array}$ & Canada & $\begin{array}{l}\text { All elderly } \\
\geq 65 \text { years }\end{array}$ & $\begin{array}{l}18 \text { Contraindicated drugs, } 16 \text { drug- } \\
\text { disease interactions, } 4 \text { DDI }\end{array}$ & No & Include DDIs \\
\hline Laroche et al. [34] & $\begin{array}{l}\text { French } \\
\text { Consensus } \\
\text { Panel List }\end{array}$ & France & $\begin{array}{l}\text { All elderly } \\
\geq 75 \text { years }\end{array}$ & $\begin{array}{l}29 \text { Drugs to be avoided. Five } \\
\text { criteria on drugs to be avoided in } \\
\text { specific medical conditions }\end{array}$ & No & $\begin{array}{l}\text { Include drug } \\
\text { duplication } \\
\text { Suggest alternative } \\
\text { therapies }\end{array}$ \\
\hline Gallagher et al. [35] & $\begin{array}{l}\text { STOPP and } \\
\text { START }\end{array}$ & $\begin{array}{l}\text { Ireland/ } \\
\text { UK }\end{array}$ & $\begin{array}{l}\text { All elderly } \\
\geq 65 \text { years }\end{array}$ & $\begin{array}{l}65 \text { Criteria on PIM (STOPP) } 22 \\
\text { criteria on prescribing omissions } \\
\text { (START) }\end{array}$ & Yes & $\begin{array}{l}\text { Include drug } \\
\text { duplication and } \\
\text { DDIs }\end{array}$ \\
\hline Basger et al. [36] & $\begin{array}{l}\text { Australian } \\
\text { Prescribing } \\
\text { Indicators } \\
\text { Tool }\end{array}$ & Australia & $\begin{array}{l}\text { All elderly } \\
\geq 65 \text { years }\end{array}$ & $\begin{array}{l}48 \text { Prescribing indicators, including } \\
18 \text { regarding avoidance of } \\
\text { medications in certain } \\
\text { diseases/conditions and } 19 \\
\text { therapy omissions }\end{array}$ & Yes & Include DDIs \\
\hline Rognstad et al. [37] & NORGEP & Norway & $\begin{array}{l}\text { All elderly } \\
\geq 70 \text { years } \\
\text { in general } \\
\text { practice }\end{array}$ & $\begin{array}{l}36 \text { Criteria- } 21 \text { on specific drugs } \\
\text { and } 15 \text { on drug combinations, } \\
\text { considered potentially } \\
\text { inappropriate }\end{array}$ & No & Include DDIs \\
\hline Holt et al. [38] & $\begin{array}{l}\text { PRISCUS } \\
\text { List }\end{array}$ & Germany & $\begin{array}{l}\text { All elderly } \\
\geq 65 \text { years }\end{array}$ & 83 PIMs & No & $\begin{array}{l}\text { Include information } \\
\text { about therapeutic } \\
\text { alternatives and } \\
\text { precautions }\end{array}$ \\
\hline $\begin{array}{l}\text { Swedish National } \\
\text { Board of Health } \\
\text { and Welfare }[23,24]\end{array}$ & $\begin{array}{l}\text { Swedish } \\
\text { indicators }\end{array}$ & Sweden & $\begin{array}{l}\text { All elderly } \\
\geq 75 \text { years }\end{array}$ & $\begin{array}{l}9 \text { Drug-specific and } 11 \text { diagnosis- } \\
\text { specific principal indicators }\end{array}$ & Yes & $\begin{array}{l}\text { Include drug } \\
\text { duplication and } \\
\text { DDIs }\end{array}$ \\
\hline
\end{tabular}

STOPP Screening Tool of Older People's Prescriptions, START Screening Tool to Alert to Right Treatment, NORGEP Norwegian General Practice, PRISCUS latin for 'time-honoured', PIM potentially inappropriate medication, DDI drug-drug interaction

\subsection{STOPP (Screening Tool of Older Person's} Prescriptions) and START (Screening Tool to Alert to Right Treatment)

The STOPP/START (Screening Tool of Older Person's Prescriptions/Screening Tool to Alert to Right Treatment) criteria [35] were developed in Ireland, with the aim of creating a tool that is easy to use for the prescriber in everyday practice, yet also containing the common errors of drug treatment in elderly people, including potentially inappropriate medications (PIMs), drug duplications, DDIs and prescribing omissions. The criteria are divided into 65 criteria for potentially inappropriate prescriptions (STOPP) and 22 criteria for therapy omissions (START), each organised by physiological systems.

\subsection{Australian Prescribing Indicators Tool}

These criteria are largely based on medical conditions, covering both drug-disease interactions and therapy omissions, and include aspects on drug dosing, renal function, DDIs and monitoring of drug effects [36]. They also address some other relevant pieces of information; for example, 'blood pressure targets', 'risk factors for impaired 
renal function' and 'sources of calcium'. However, the criteria are mainly built on Australian information sources, such as data on common medical conditions and medications among older people, consensus documents and clinical guidelines, and may therefore not be fully applicable in other countries.

\subsection{NORGEP (Norwegian General Practice) Criteria}

The NORGEP (Norwegian General Practice) criteria published in 2009, were developed for patients in general practice and contain two lists, one about single drugs and drug dosages and one about drug combinations, considered potentially pharmacologically inappropriate for elderly patients [37]. The NORGEP criteria have been criticised for containing several drugs that are rarely used in clinical practice $[26,27]$.

\subsection{PRISCUS List}

The PRISCUS list [38] comprises 83 drugs among a total of 18 drug classes, rated as potentially inappropriate for elderly patients. They do not address other aspects of quality of drug use, but provide information regarding possible therapeutic alternatives, as well as precautions to be taken whenever the listed inappropriate medications are used.

\section{The Swedish Indicators for Quality of Drug Therapy in the Elderly}

\subsection{Development}

The starting point for the development of the Swedish indicators were the explicit criteria available at the time, i.e. the first version of the Beers criteria [28] and the Canadian criteria [33]. Other sources were recommendations and guidelines from Swedish authorities and organisations, including the Swedish Medical Products Agency, the Swedish National Board of Health and Welfare, the Swedish Council on Health Technology Assessment and the Swedish strategic programme against antibiotic resistance. DDIs were to be assessed according to the interaction database in Sweden at that time [39].

The indicators were designed to be applicable to people aged 75 years and over, regardless of residence and other characteristics. It was decided to include both indicators about drug therapy regardless of diagnoses (drug-specific) and about drug therapy in some common conditions (diagnosis-specific). Novelties compared with previously published criteria at that time were the inclusion of indicators about drug duplications, drug use without proper indication and about dosage regimens. Moreover, the diagnosis-specific indicators were to include not only drugdisease interactions but also aspects of adherence to treatment recommendations. Thus, the indicators were supposed to be not only 'negative', reflecting IDU, but also 'positive', pointing at treatment that is potentially beneficial but sometimes omitted in eldercare.

The indicators were divided into (a) drug-specific, covering choice, indication and dosage of drugs, aspects of polypharmacy and DDIs; and (b) diagnosis-specific, covering rational, irrational and hazardous drug use in 11 common disorders in elderly people.

The indicators were validated through a consensus approach using a modified Delphi technique. The preliminary list was assessed by an expert panel consisting of a clinical pharmacologist, a pharmacist, two general practitioners, a geriatrician, a geropsychiatrist and a representative from the Swedish Medical Products Agency. After revision, a second proposal was published on the Web and the Swedish drug committees, heads of outpatient care and municipality chief nurses were asked to comment on the different indicators. Following a second revision, a final document was published in January 2004.

This first version comprised six principal drug-specific indicators, each containing 1-7 individual items, and 11 principal diagnosis specific indicators, each with 3-10 items on rational, irrational and hazardous drug treatment (Table 2).

During 2008-2010 the indicators were revised and updated. This time, the procedure was somewhat different. The drug-specific indicators were reviewed in close collaboration with an expert group including one clinical pharmacologist, four pharmacists, one general practitioner, one geriatrician, one nurse, two municipality chief nurses, one pharmacoepidemiologist and one representative from the Swedish Medical Products Agency. The diagnosis-specific indicators were reviewed by representatives from the Swedish drug committees, each of the 11 principal indicators being independently revised by two different committees. The revision resulted in some major changes:

- one indicator was added regarding drug use in decreased renal function;

- one indicator was added regarding drug use and certain symptoms that may reflect adverse drug reactions;

- one indicator was added regarding the best choice of anxiolytic and hypnotic drugs;

- the indicator on arthrosis was replaced by an indicator on pain treatment.

In addition many indicators were updated to meet new recommendations, or to adapt to the current Swedish drug formulary, and in many cases were expanded. 
Table 2 Overview of the principal indicators in the first (2004) version of the Swedish indicators for quality of drug therapy in the elderly

\begin{tabular}{|c|c|}
\hline Indicator & $\begin{array}{l}\text { No. of } \\
\text { items }\end{array}$ \\
\hline \multicolumn{2}{|l|}{ 1. Drug-specific indicators } \\
\hline $\begin{array}{l}\text { 1.1 Drugs that should be avoided unless specific } \\
\text { reasons exist }\end{array}$ & 5 \\
\hline $\begin{array}{l}\text { 1.2 Drugs for which the use requires a correct and } \\
\text { current indication }\end{array}$ & 7 \\
\hline 1.3 Inappropriate dosage regimen & 3 \\
\hline 1.4 Inappropriate daily dose & 7 \\
\hline 1.5 Polypharmacy & 2 \\
\hline \multicolumn{2}{|l|}{ Use of three or more psychotropic drugs } \\
\hline \multicolumn{2}{|l|}{ Drug duplication } \\
\hline $\begin{array}{l}\text { 1.6 Drug combinations that may lead to clinically } \\
\text { relevant drug-drug interactions }\end{array}$ & 1 \\
\hline \multicolumn{2}{|l|}{ 2. Diagnosis-specific indicators } \\
\hline 2.1 Hypertension & 3 \\
\hline 2.2 Ischemic heart disease-angina pectoris & 5 \\
\hline 2.3 Heart failure & 7 \\
\hline 2.4 Chronic obstructive pulmonary disease & 4 \\
\hline 2.5 Diabetes, type 2 & 3 \\
\hline $\begin{array}{l}\text { 2.6 Gastroesophageal reflux disease and peptic ulcer } \\
\text { disease }\end{array}$ & 5 \\
\hline 2.7 Urinary tract infection & 10 \\
\hline 2.8 Arthrosis & 4 \\
\hline 2.9 Dementia & 3 \\
\hline 2.10 Depression & 3 \\
\hline 2.11 Sleep disturbance & 4 \\
\hline
\end{tabular}

The DDIs were now recommended to be assessed by using a new database, SFINX [40], which since then has been implemented in most computerised patient records and other decision support systems in Sweden.

\subsection{Structure}

As in the first version from 2004 [23], the updated (2010) version [24] of the Swedish indicators are divided into drug-specific and diagnosis-specific indicators. All indicators have a common structure. They refer to the proportion of individuals using a certain inappropriate, rational, irrational or hazardous medication. Moreover, they do not specify levels of use but only state the preferred direction (standard): 'as low as possible' or 'as high as possible' (Figs. 1, 2).

\section{Indicator}

Proportion (percent) of individuals using

- Long acting benzodiazepines (N05BA01, N05CD02, N05CD03)

- Drugs with significant anticholinergic properties (N04A, N06AA, N05BB01 etc)

- Tramadol (N02AX02)

- Propiomazine (N05CM06)

Standard

Proportion (percent individuals) should be as low as possible

Fig. 1 The structure of a drug-specific indicator from the Swedish indicators for quality of drug therapy in the elderly, exemplified by indicator 1.1 'Drugs that should be avoided unless specific reasons exist', consisting of four items. ATC codes for the included drugs are presented within brackets. ATC Anatomical Therapeutic Chemical

\subsubsection{Drug-Specific Indicators}

The updated version [24] includes nine principal drugspecific indicators, each comprising 1-8 individual items (Table 3; Fig. 1). Anatomical Therapeutic Chemical (ATC) codes are included to define the drugs or drug groups. These indicators do not only define inappropriate drugs but also cover indication for drug use, dosage regimens, maximum daily doses of some important drugs, aspects of polypharmacy, DDIs, drugs that need dose adjustments in decreased renal function, drugs that are implicated in some important adverse drug reactions and some aspects on psychotropic drugs (Table 3).

\subsubsection{Diagnosis-Specific Indicators}

The 2010 update [24] consists of 11 principal diagnosisspecific indicators, each covering 2-9 items on rational, irrational and hazardous drug treatment in common disorders in old age (Table 3; Fig. 2). The indicators on hazardous drug treatment represent drug-disease interactions, whereas those on rational drug treatment can be used to indicate therapy omissions. The indicators on irrational drug treatment include drugs that are neither hazardous nor beneficial with the specified diagnosis. They just represent an unnecessary addition to the drug list and, what is worse, may in some cases be a substitute for a better therapy. One example of this is oral $\beta$-2-receptor agonists in chronic obstructive pulmonary disease. 


\section{Indicator}

Proportion (percent) of individuals using

- Low-dose ASA, of all individuals with ischemic heart disease - angina pectoris

- Beta-receptor blocking agents, of all individuals with ischemic heart disease angina pectoris

Standard

Proportion (percent individuals) should be as high as possible

- ASA in a daily dose $>75 \mathrm{mg}$, of all individuals with ischemic heart disease angina pectoris treated with low-dose ASA

- Organic nitrates without nitrate-free period, of all individuals with ischemic heart disease - angina pectoris treated with organic nitrates

- Diltiazem or verapamil, of all individuals with ischemic heart disease - angina pectoris and concurrent heart failure

- Diltiazem or verapamil in combination with a beta-receptor blocking agent

Standard

Proportion (percent individuals) should be as low as possible

Fig. 2 The structure of a diagnosis-specific indicator from the Swedish indicators for quality of drug therapy in the elderly, exemplified by indicator 2.2 'Ischemic heart disease-angina pectoris'. The indicator consists of six items, the first two about rational drug use and the remaining four about irrational or hazardous drug use. $A S A$ acetylsalicylic acid

\section{Comparison with Other Criteria/Indicators}

The Swedish indicators were relatively comprehensive, particularly when it is considered that they were introduced as early as 2004. Indeed, at that time only the second update of the Beers' criteria [30] and the McLeod criteria [33] were available among the explicit criteria. The Swedish indicators not only comprised indicators on drug-disease interactions but also therapy omissions, both included among the diagnosis-specific indicators. In addition, both DDIs and drug duplications, as well as drug indications and dosages, were addressed. With the update 2010, more aspects on quality of medication were added; for example, on drug use in decreased renal function.

There are some clear differences between the Swedish indicators and other explicit criteria/indicators, in assigning medications as appropriate or inappropriate. Some of the drugs considered inappropriate in many other lists are even presented as rational therapy according to the Swedish indicators; for example, zopiclone, spironolactone and nitrofurantoin. Conversely, some drugs considered inappropriate by the Swedish indicators are not found in other lists; for example, tramadol and propiomazine.

Among the currently available criteria/indicators, the Swedish ones would be most comparable to the STOPP and START criteria [35], which cover aspects on both IDU and therapy omissions, as well as DDIs and drug duplication.

Unlike the French consensus panel list [34] and the PRISCUS list [38], the Swedish indicator set does not include any information about therapeutic alternatives. However, this is intentional as one of the major aims of the indicators was that their use should not circumscribe the physician's opportunity to make a qualified decision.

\section{Applications of the Swedish Indicators}

From the first version, the indicators were proposed to have the following fields of applications:

- as a support for prescribing drugs to elderly people;

- in different types of local follow-ups and interventions, for example drug utilisation reviews for elderly people in ordinary homes or nursing homes;

- for follow-up of prescription patterns;

- for national surveys and epidemiological studies.

The indicators can thus both provide support for improving the quality of older people's drug therapy and serve as tools for monitoring drug therapy.

Ten years after introduction, the indicators are well established in Swedish healthcare and have brought on several initiatives and applications along the way.

\subsection{Actions from Drug and Therapeutic Committees}

In 2006, the Swedish regional drug and therapeutic committees launched a national campaign for improving drug use in elderly people ('Nationella kraftsamlingen'), where one of the main objectives was to pave the way for the indicators to have an impact on Swedish healthcare. This resulted in not only several educational initiatives in geriatric pharmacology for healthcare personnel but also the creation of regional recommendations for drug therapy in older people, largely based on the indicators.

\subsection{Prescribing Support}

Within a year of publishing the first version of the indicators, quick reference guides were developed by some regional drug and therapeutic committees, summarising the most clinically relevant indicators, including inappropriate drugs-such as long-acting benzodiazepines and anticholinergic drugs-and drugs that should be prescribed with caution to elderly people; for example, non-steroidal anti-inflammatory drugs (NSAIDs), opioids and antipsychotics. Today, most Swedish counties have their own reference guide for drug prescribing to older persons.

Later, the indicators were also implemented in some computerised decision support systems for prescribing to elderly patients and drug utilisation reviews [41]. 
Table 3 Overview of the indicators in the second (2010) version of the Swedish indicators for quality of drug therapy in the elderly

\begin{tabular}{ll}
\hline Indicator & $\begin{array}{l}\text { No. of Examples } \\
\text { items }\end{array}$ \\
\hline
\end{tabular}

\section{Drug-specific indicators}

1.1 Drugs that should be avoided unless specific reasons exist

1.2 Drugs for which the use requires a correct and current indication

1.3 Inappropriate dosage regimen

1.4 Inappropriate daily dose

\subsection{Polypharmacy}

Use of ten or more drugs

Use of three or more psychotropic drugs

Drug duplication

1.6 Drug combinations that may lead to clinically relevant drug-drug interactions

1.7 Drug use and renal function

1.8 Drug use and certain symptoms

Symptomatic orthostatic hypotension

Falls

Cognitive impairment

1.9 Psychotropic drugs

Inappropriate anxiolytics and hypnotics

Best-choice anxiolytics and hypnotics

2. Diagnosis-specific indicators

2.1 Hypertension

2.2 Ischemic heart disease-angina pectoris

2.3 Heart failure

2.4 Chronic obstructive pulmonary disease

2.5 Diabetes, type 2

2.6 GERD and peptic ulcer disease

2.7 UTI

2.8 Pain

2.9 Dementia

2.10 Depression

2.11 Sleep disturbance

2
Long-acting benzodiazepines

Drugs with significant anticholinergic properties

Tramadol

NSAIDs

Opioids

SSRIs

Antipsychotics

Proton pump inhibitors

Hypnotics, $>1$ month of regular use

Antiepileptics $>1$ year without review

Antipsychotics $>3$ months without review

Low-dose ASA, daily dose $>75 \mathrm{mg}$

Risperidone, daily dose $>1.5 \mathrm{mg}$

Oxazepam, daily dose $>30 \mathrm{mg}$

Two or more opioids or hypnotics

Potassium + potassium-sparing agents

Warfarin + NSAID

Metformin, digoxin, potassium-sparing diuretics, atenolol

Calcium channel blockers, antipsychotics

Diuretics, hypnotics, antidepressants

Anticholinergic drugs, opioids, antiepileptics

Diazepam, propiomazine

Oxazepam, zopiclone

Hazardous: cardioselective calcium channel blocker in concurrent heart failure

Rational: low-dose ASA, daily dose $75 \mathrm{mg}$

Rational: ACE inhibitor or angiotensin-II antagonist, $\beta$-receptor blocker

Hazardous: NSAID, Cardioselective calcium channel blocker

Irrational: oral $\beta$-2-receptor agonist

Hazardous: non-selective $\beta$-receptor blocker

Hazardous: metformin with decreased renal function (estimated GFR $<60 \mathrm{ml} / \mathrm{min}$ ), glibenclamide

Hazardous: NSAID with a history of GERD or peptic ulcer

Rational: pivmecillinam, nitrofurantoin or trimethoprim in UTI in women

Hazardous: quinolone antibacterials

Hazardous: NSAIDs—continuous treatment, tramadol

Rational: cholinesterase inhibitor or memantine, if effect is ascertained

Hazardous: drugs with significant anticholinergic properties

Irrational: prescription of anxiolytics and hypnotics without antidepressant treatment

Hazardous: triazolam, propiomazine, alimemazine, hydroxyzine and promethazine

NSAID non-steroidal anti-inflammatory drug, SSRI selective serotonin reuptake inhibitor, $A S A$ acetylsalicylic acid, $A C E$ angiotensin-converting enzyme, GERD gastroesophageal reflux disease, UTI urinary tract infection, GFR glomerular filtration rate 


\subsection{Drug Utilisation Reviews}

The Swedish indicators have been extensively used for many years in drug utilisation reviews for both nursing home and ambulatory older persons [41, 42]. Here, both the drug- and diagnosis-specific indicators can be used for identifying potential drug-related problems, such as the use of inappropriate drugs, duplicate use, DDIs and contraindicated drug use in some diseases. In a nursing-home study, where an extensive part of the Swedish indicators were used, these reviews led to marked improvements with respect to anticholinergic drugs (part of indicator 1.1; $40 \%$ decrease), drug duplication (part of indicator $1.5 ; 30 \%$ decrease), DDI (indicator 1.6; $41 \%$ decrease) and hazardous drug use in some diagnoses (diagnosis-specific indicators; $48 \%$ decrease) [41].

\subsection{National Benchmarking}

Annually, since 2006 the Swedish National Board of Health and Welfare and the Swedish Association of Local Authorities and Regions (SALAR) have jointly published regional comparisons of quality and efficiency in Swedish healthcare, where the 21 counties are compared by using more than 100 indicators [43]. Among these, five measure the quality of drug use in older people: drugs that should be avoided unless specific reasons exist (indicator 1.1), use of ten or more drugs and use of three or more psychotropic drugs (both from indicator 1.5), drug combinations that may lead to clinically relevant drug-drug interactions (indicator 1.6) and use of best-choice hypnotics (from indicator 1.9). These are applied to computerised analyses of the Swedish Prescribed Drug Register (SPDR), an individual-based register covering all dispensed prescriptions to the whole Swedish population, of which around 740,000 people are aged 75 years and older [44].

Since 2008, a similar set of drug-specific indicators have been analysed at the municipality and urban district level and published annually on the Web in the so-called Äldreguiden ('Elderly guide'), providing elderly people and their relatives with the possibility of comparing the quality of eldercare, including levels of inappropriate medication, in different geographical areas of Sweden [45].

\subsection{Pay for Performance}

In 2010, the Swedish government and SALAR made an agreement to support long-term improvement work with a focus on better quality and cohesiveness of the care of the most ill elderly persons. This included a pay for performance model, where the Swedish counties and municipalities were monitored with respect to different indicators of quality of care, and awarded when attaining the performance goals [45]. Among the indicators is one set of three on the quality of drug use, including drugs that should be avoided unless specific reasons exist (indicator 1.1), NSAIDs and antipsychotics (both from indicator 1.2). During this initiative, in 2011-2014, drugs that should be avoided unless specific reasons exist (indicator 1.1) decreased by $27 \%$, NSAIDs by $28 \%$ and antipsychotics by $12 \%$ in persons 75 years and older.

\subsection{Initiative from Pensioner Organisations}

'Koll på läkemedel' ('Keep track of your medications') is a collaboration between two of the largest Swedish pensioner organisations and one Swedish pharmacy company, working for better drug treatment in elderly people. Their purpose is to educate and support patients to improve their own treatment, and one of the more appreciated products is the 'Olämpliga listan' ('Inappropriate list'), derived from indicator 1.1 .

\subsection{Epidemiological Studies}

The Swedish indicators have been used in around 15 different epidemiological studies, describing quality of drug use in the elderly population in general [44] and in nursing homes [21, 46, 47], and investigating areas such as sex differences [48], influence of education [3, 18], association with institutionalisation [47], effect of multidose drug dispensing $[49,50]$ and the association with hospitalisation and mortality [7]. Among others, these studies have demonstrated significant associations between IDU and female sex [48], institutional living [47], low educational attainment [3] and multidose dispensing [49].

\subsection{Regulations}

In 2012, the Swedish National Board of Health and Welfare [51] launched regulations imposing healthcare providers to offer medication reviews to all patients aged 75 years or older, using $\geq 5$ drugs. In the associated guidance [52], they recommend the use of the indicators in these reviews.

\section{Improvements in Quality of Drug Use}

Since 2005, we have observed signs of improvement in the quality of drug prescribing in the elderly population in Sweden. In a report from the National Board of Health and Welfare [53], analyses of the SPDR showed that the prescribing of drugs that should be avoided unless specific reasons exist (indicator 1.1) had decreased by $36 \%$ between 2006 and 2012 in persons aged 80 years and older. Similarly, drug combinations that may lead to clinically 
relevant drug-drug interactions (1.6) decreased by $26 \%$. Among psychotropic drugs, antipsychotics reduced by $41 \%$, anxiolytics by $12 \%$ and hypnotics by $10 \%$. In contrast, the polypharmacy indicator use of 10 or more drugs (1.5) did not change (11\% in both 2006 and 2012) in this age group.

A more recent study [54] largely confirms these results. Measurements from the SPDR between 2006 and 2013 show improvements in people aged 75 years and older, according to all but one drug-specific indicator, covering drugs that should be avoided unless specific reasons exist (1.1), use of three or more psychotropic drugs (1.5) and best-choice anxiolytics and hypnotics (1.9). However, the indicator use of 10 or more drugs (1.5) was virtually unchanged. The authors conclude that "prescribers appear to be more likely to change their prescribing patterns for the elderly than previously assumed" [54].

A few studies from other countries have also examined the trend in inappropriate medication over time. In an American study of community-dwelling elderly people $\geq 65$ years of age, IDU, as evaluated by using the Beers' 1997 criteria [29], declined from $24.8 \%$ in 1995 to $21.3 \%$ in 1999, i.e. a $14 \%$ reduction [55]. An Italian study of a similar age group of community dwellers, over the same time period, evaluated with Beers' 1991 criteria [28], reported a greater decrease, by $44 \%$ (from 9.1 to $5.1 \%$ ); however, at the same time, potentially major DDIs increased by $19 \%$ [56].

A study using a French update of the Beers 1997 [29] criteria showed a mean annual decrease in PIM rate of $3.6 \%$ between 1995 and 2004 [57]. However, the decrease was only seen for two drug groups (cerebral vasodilators and long-acting benzodiazepines).

In a more recent study from Germany, comparing 2003 and 2009, PIM prevalence evaluated by using the German PRISCUS list, in ambulatory people aged 75 years or more, was reduced from 29 to $25 \%$, corresponding to a $14 \%$ decrease [58].

Thus, the decrease in IDU observed in the Swedish elderly population since 2006 is largely beyond what has been observed in other studies of long-term trends in medication use. Although we cannot establish a causal relationship between this positive development and the advent of the Swedish indicators, it is reasonable to assume that they have contributed to this positive trend.

Many types of interventions can lead to a reduction in IDU in elderly people, ranging from educational interventions, computerised support systems, pharmacist interventions, geriatric medicine services, multidisciplinary team reviews and regulatory policies [59]. As described above, the Swedish indicators have, to some extent, had an impact on all these types of interventions. Thus, the Swedish indicators may have promoted the 'combined efforts' [59] that are probably necessary to make a sustainable improvement of the quality of drug treatment in elderly patients.

\section{Limitations}

A general weakness of consensus-based criteria/indicators is that they can never be fully applicable to the heterogeneous population of drug responders that aged people represent. They are a crude tool and their use needs to be adjusted to the clinical situation. Drug use deemed inappropriate may sometimes be indicated for the individual patient or in a particular clinical situation, when the benefit is estimated to outweigh the risk. This means, for example, that this type of criteria/indicators may overestimate the prevalence of inappropriate drug prescribing in epidemiological studies.

Another limitation is the general lack of information regarding adherence to the drug therapy. This is common to all measures of drug use, but non-adherence is more frequent in the elderly population with polypharmacy [60], and most likely also with IDU.

Finally, we do not know to what extent the improved quality of drug therapy in older people in Sweden has translated into improved health of the elderly. This needs to be further investigated in terms of public health outcomes in the Swedish elderly population.

\section{Conclusions}

The indicators on the quality of drug therapy in the elderly, developed by the Swedish National Board of Health and Welfare, were first published in 2004 and updated in 2010. They comprise several aspects of quality of drug prescribing, including inappropriate drugs, indication of drug use, drug dosage, polypharmacy, drug duplications, DDIs, drug use in decreased renal function, drug symptom/disease interactions and therapy omissions.

The indicators have been well received by Swedish healthcare, authorities, politicians, researchers and pensioner organisations. During the 10 years since their release, they have been employed in many different activities to improve the quality of drug use in elderly persons, including prescribing support, drug utilisation reviews and national benchmarking. They also form the basis for recommendations on drug treatment in old age, several scientific publications, and have promoted many educational initiatives in this area, both for healthcare personnel and for older persons and their relatives.

During this time, several measures of the quality of drug use in the Swedish elderly population have shown 
significant improvements; for example, a decreased prevalence of drugs that should be avoided, drug combinations that may lead to DDIs and several types of psychotropic drugs.

Therefore, the Swedish indicators may be seen as a successful national initiative that has translated into local initiatives, research in geriatric pharmacoepidemiology, and contributed to better drug treatment in old age.

Acknowledgments Kristina Johnell is funded by a Grant from the Swedish Research Council.

Johan Fastbom has participated in the development of the Swedish indicators. Kristina Johnell has no potential conflicts of interest that are directly relevant to the content of this review.

Open Access This article is distributed under the terms of the Creative Commons Attribution Noncommercial License which permits any noncommercial use, distribution, and reproduction in any medium, provided the original author(s) and the source are credited.

\section{References}

1. Maher RL, Hanlon J, Hajjar ER. Clinical consequences of polypharmacy in elderly. Expert Opin Drug Saf. 2014;13(1):57-65.

2. Jyrkkä J, Vartiainen L, Hartikainen S, et al. Increasing use of medicines in elderly persons: a five-year follow-up of the Kuopio 75 + Study. Eur J Clin Pharmacol. 2006;62(2):151-8.

3. Haider SI, Johnell K, Ringbäck Weitoft G, et al. The influence of educational level on polypharmacy and inappropriate drug use: a register-based study of more than 600,000 older people. J Am Geriatr Soc. 2009;57:62-9.

4. Johnell K, Fastbom J. Comparison of prescription drug use between community-dwelling and institutionalized elderly in Sweden. Drugs Aging. 2012;29:751-8.

5. Beyth RJ, Shorr RI. Principles of drug therapy in older patients: rational drug prescribing. Clin Geriatr Med. 2002;18(3):577-92.

6. Hubbard RE, O'Mahony MS, Woodhouse KW. Medication prescribing in frail older people. Eur $\mathrm{J}$ Clin Pharmacol. 2013;69(3):319-26.

7. Klarin I, Wimo A, Fastbom J. The association of inappropriate drug use with hospitalisation and mortality: a population-based study of the very old. Drugs Aging. 2005;22:69-82.

8. Lau DT, Kasper JD, Potter DEB, et al. Hospitalization and death associated with potentially inappropriate medication prescriptions among elderly nursing home residents. Arch Intern Med. 2005; 165(1):68-74.

9. Ruggiero C, Dell'Aquila G, Gasperini B, et al. Potentially inappropriate drug prescriptions and risk of hospitalization among older, Italian, nursing home residents: the ULISSE project. Drugs Aging. 2010;27(9):747-58.

10. Gosch M, Wörtz M, Nicholas JA, et al. Inappropriate prescribing as a predictor for long-term mortality after hip fracture. Gerontology. 2014;60(2):114-22.

11. Price SD, Holman CDJ, Sanfilippo FM, et al. Association between potentially inappropriate medications from the Beers criteria and the risk of unplanned hospitalization in elderly patients. Ann Pharmacother. 2014;48(1):6-16.

12. Fialová D, Topinková E, Gambassi G, AdHOC Project Research Group, et al. Potentially inappropriate medication use among elderly home care patients in Europe. JAMA. 2005;293(11):1348-58.

13. Gallagher P, Barry P, O'Mahony D. Inappropriate prescribing in the elderly. J Clin Pharm Ther. 2007;32(2):113-21.
14. Guaraldo L, Cano FG, Damasceno GS, et al. Inappropriate medication use among the elderly: a systematic review of administrative databases. BMC Geriatr. 2011;11:79.

15. Schubert I, Küpper-Nybelen J, Ihle $P$, et al. Prescribing potentially inappropriate medication (PIM) in Germany's elderly as indicated by the PRISCUS list. An analysis based on regional claims data. Pharmacoepidemiol Drug Saf. 2013;22(7):719-27.

16. Galvin R, Moriarty F, Cousins G, et al. Prevalence of potentially inappropriate prescribing and prescribing omissions in older Irish adults: findings from The Irish LongituDinal Study on Ageing study (TILDA). Eur J Clin Pharmacol. 2014;70(5):599-606.

17. Giron MT, Claesson C, Thorslund M, et al. Drug use patterns in a very elderly population. A seven-year review. Clin Drug Inv. 1999;17:389-98.

18. Haider SI, Johnell K, Thorslund M, et al. Trends in polypharmacy and potential drug-drug interactions across educational groups in elderly patients in Sweden for the period 1992-2002. Int J Clin Pharmacol Ther. 2007;45(12):643-53.

19. Björck Linné A, Liedholm H. Audit of prescribing practices in nursing homes. Many medications but few serious interactions. Lakartidningen. 2003;100:2360-5.

20. Kragh A. Two out of three persons living in nursing homes for the elderly are treated with at least ten different drugs. A survey of drug prescriptions in the northeastern part of Skane. Lakartidningen. 2004;101(11):994-6.

21. Olsson J, Bergman A, Carlsten A, et al. Quality of drug prescribing in elderly people in nursing homes and special care units for dementia: a cross-sectional computerized pharmacy register analysis. Clin Drug Investig. 2010;30(5):289-300.

22. Weitoft GR, Ericsson O, Fastbom J. Prescription drugs: Health in Sweden: The National Public Health Report 2012. Chapter 18. Scand J Public Health. 2012;40(9 Suppl):293-304.

23. Indikatorer för utvärdering av kvaliteten i äldres läkemedelsterapi. Swedish National Board of Health and Welfare (Socialstyrelsen); 2004. 2003-110-20.

24. Indikatorer för god läkemedelsterapi hos äldre. Swedish National Board of Health and Welfare (Socialstyrelsen); 2010. 2010-6-29. Available at: http://www.socialstyrelsen.se/publikationer2010/ 2010-6-29. Accessed 28 Jan 2015.

25. Gnjidic D, Johnell K. Clinical implications from drug-drug and drug-disease interactions in older people. Clin Exp Pharmacol Physiol. 2013;40:320-5.

26. Levy HB, Marcus EL, Christen C. Beyond the Beers criteria: a comparative overview of explicit criteria. Ann Pharmacother. 2010;44(12):1968-75.

27. O'Connor MN, Gallagher P, O'Mahony D. Inappropriate prescribing: criteria, detection and prevention. Drugs Aging. 2012;29(6):437-52.

28. Beers MH, Ouslander JG, Rollingher I, et al. Explicit criteria for determining inappropriate medication use in nursing home residents. UCLA Division of Geriatric Medicine. Arch Intern Med. 1991;151(9):1825-32.

29. Beers MH. Explicit criteria for determining potentially inappropriate medication use by the elderly: an update. Arch Intern Med. 1997;157(14):1531-6.

30. Fick DM, Cooper JW, Wade WE, et al. Updating the Beers criteria for potentially inappropriate medication use in older adults: results of a US consensus panel of experts. Arch Intern Med. 2003;163(22):2716-24.

31. American Geriatrics Society 2012 Beers Criteria Update Expert Panel. American Geriatrics Society updated Beers criteria for potentially inappropriate medication use in older adults. J Am Geriatr Soc. 2012;60(4):616-31.

32. van der Hooft CS, Jong GW, Dieleman JP, et al. Inappropriate drug prescribing in older adults: the updated 2002 Beers criteria-a population-based cohort study. $\mathrm{Br} \mathrm{J}$ Clin Pharmacol. 2005;60(2):137-44. 
33. McLeod PJ, Huang AR, Tamblyn RM, et al. Defining inappropriate practices in prescribing for elderly people: a national consensus panel. CMAJ. 1997;156(3):385-91.

34. Laroche ML, Charmes JP, Merle L. Potentially inappropriate medications in the elderly: a French consensus panel list. Eur J Clin Pharmacol. 2007;63(8):725-31.

35. Gallagher P, Ryan C, Byrne S, et al. STOPP (Screening Tool of Older Person's Prescriptions) and START (Screening Tool to Alert doctors to Right Treatment). Consensus validation. Int J Clin Pharmacol Ther. 2008;46(2):72-83.

36. Basger BJ, Chen TF, Moles RJ. Inappropriate medication use and prescribing indicators in elderly Australians: development of a prescribing indicators tool. Drugs Aging. 2008;25(9):777-93.

37. Rognstad S, Brekke M, Fetveit A, et al. The Norwegian General Practice (NORGEP) criteria for assessing potentially inappropriate prescriptions to elderly patients. A modified Delphi study. Scand J Prim Health Care. 2009;27(3):153-9.

38. Holt S, Schmiedl S, Thürmann PA. Potentially inappropriate medications in the elderly: the PRISCUS list. Dtsch Arztebl Int. 2010;107(31-32):543-51.

39. Sjöqvist F. A new classification system for drug interactions. Eur J Clin Pharmacol. 1997;52 Suppl.:327a

40. Böttiger Y, Laine K, Andersson ML, et al. SFINX-a drug-drug interaction database designed for clinical decision support systems. Eur J Clin Pharmacol. 2009;65(6):627-33.

41. Ulfvarson J, Rahmner PB, Fastbom J, et al. Medication reviews with computerised expert support: evaluation of a method to improve the quality of drug utilisation in the elderly. Int J Health Care Qual Assur. 2010;23(6):571-82.

42. Milos V, Rekman E, Bondesson $\AA$, et al. Improving the quality of pharmacotherapy in elderly primary care patients through medication reviews: a randomised controlled study. Drugs Aging. 2013;30(4):235-46.

43. Quality and efficiency in Swedish health care: regional comparisons 2012. Swedish National Board of Health and Welfare and Swedish Association of Local Authorities and Regions 2013-5-7. Available at: http://www.socialstyrelsen.se/publikationer2013/ 2013-5-7. Accessed 28 Jan 2015.

44. Johnell K, Fastbom J, Rosén M, et al. Inappropriate drug use in the elderly: a nationwide register-based study. Ann Pharmacother. 2007;41(7):1243-8.

45. Highlights from: a good life in old age? Monitoring and improving quality in long-term care. OECD Publishing, 2013. Available at: http://www.oecd.org/els/health-systems/SwedenOECD-EC-Good-Time-in-Old-Age.pdf. Accessed 28 Jan 2015.

46. Bergman A, Olsson J, Carlsten A, et al. Evaluation of the quality of drug therapy among elderly patients in nursing homes. Scand $\mathbf{J}$ Prim Health Care. 2007;25(1):9-14.

47. Haasum Y, Fastbom J, Johnell K. Institutionalization as a risk factor for inappropriate drug use in the elderly: a Swedish nationwide register-based study. Ann Pharmacother. 2012;46(3): 339-46.
48. Johnell K, Weitoft GR, Fastbom J. Sex differences in inappropriate drug use: a register-based study of over 600,000 older people. Ann Pharmacother. 2009;43(7):1233-8.

49. Sjöberg C, Edward C, Fastbom J, et al. Association between multi-dose drug dispensing and quality of drug treatment: a register-based study. PLoS One. 2011;6(10):e26574.

50. Wallerstedt SM, Fastbom J, Johnell K, et al. Drug treatment in older people before and after the transition to a multi-dose drug dispensing system-a longitudinal analysis. PLoS One. 2013;8(6):e67088.

51. SOSFS 2012:9 Ändring i föreskrifterna och allmänna råden (SOSFS 2000:1) om läkemedelshantering i hälso- och sjukvården. Available at: http://www.socialstyrelsen.se/ publikationer2012/2012-6-43. Accessed 28 Jan 2015.

52. Läkemedelsgenomgångar för äldre ordinerade fem eller fler läkemedel. Swedish National Board of Health and Welfare 2013-3-18. Available at: http://www.socialstyrelsen.se/ publikationer2013/2013-3-18. Accessed 28 Jan 2015.

53. Stimulansbidrag till insatser för vård och omsorg om äldreSlutredovisning perioden 2007-2012. Swedish National Board of Health and Welfare 2013-10-27. Available at: http://www. socialstyrelsen.se/publikationer2013/2013-10-27. Accessed 28 Jan 2015.

54. Hovstadius B, Petersson G, Hellström L, et al. Trends in inappropriate drug therapy prescription in the elderly in Sweden from 2006 to 2013: assessment using national indicators. Drugs Aging. 2014;31(5):379-86.

55. Stuart B, Kamal-Bahl S, Briesacher B, et al. Trends in the prescription of inappropriate drugs for the elderly between 1995 and 1999. Am J Geriatr Pharmacother. 2003;1(2):61-74.

56. Lapi F, Pozzi C, Mazzaglia G, et al. Epidemiology of suboptimal prescribing in older, community dwellers: a two-wave, population-based survey in Dicomano, Italy. Drugs Aging. 2009;26(12):1029-38.

57. Bongue B, Naudin F, Laroche ML, et al. Trends of the potentially inappropriate medication consumption over 10 years in older adults in the East of France. Pharmacoepidemiol Drug Saf. 2009;18(12):1125-33.

58. Zimmermann T, Kaduszkiewicz H, van den Bussche H, AgeCoDe-Study Group, et al. Potentially inappropriate medication in elderly primary care patients: a retrospective, longitudinal analysis [in German]. Bundesgesundheitsblatt Gesundheitsforschung Gesundheitsschutz. 2013;56(7):941-9.

59. Kaur S, Mitchell G, Vitetta L, et al. Interventions that can reduce inappropriate prescribing in the elderly: a systematic review. Drugs Aging. 2009;26(12):1013-28.

60. Pasina L, Brucato AL, Falcone C, et al. Medication non-adherence among elderly patients newly discharged and receiving polypharmacy. Drugs Aging. 2014;31(4):283-9. 